\title{
Antihypertensive Peptides in Dairy Products
}

\author{
M Zeki Durak ${ }^{1 *}$ and Neslihan Atlıhan Turan² \\ ${ }^{1}$ Department of Food Engineering, Yildiz Technical University, Turkey \\ ${ }^{2}$ Central Research Institute of Food and Feed Control, Turkey
}

*Corresponding author: M Zeki Durak, Department of Food Engineering, Chemical and Metallurgical Engineering Faculty, Yildiz Technical University, Davutpasa Campus, 34210 Esenler, Istanbul, Turkey.

To Cite This Article: M Zeki Durak, Antihypertensive Peptides in Dairy Products. 2020 - 7(2). AJBSR.MS.ID.001139.

DOI: 10.34297/AJBSR.2020.07.001139.

Received: 眥 February 03, 2020; Published: 制 February 11, 2020

\begin{abstract}
Dairy products are a fundamental source of protein. Also, they are popular foods for the intake of bioactive peptides with their sensory properties and high consumption. Among various bioactivities, antihypertensive activity has special importance due to high blood pressure, which has become a growing health problem in recent years. Milk proteins are the main precursors for ACE inhibitor peptides. The antihypertensive effect of a few bioactive peptides found in dairy products has been confirmed in vivo, and a few commercial products have shown to reduce blood pressure. This review discusses the studies about the antihypertensive specifically ACE inhibitor peptides found in milk and dairy products as an essential source of bioactive peptides.
\end{abstract}

Keywords: Bioactive Peptides; Milk; Dairy Products; ACE Inhibitor; Antihypertensive

\section{Introduction}

Milk and dairy products are rich in protein content, and main proteins in milk casein and whey proteins are the principle bioactive peptide precursors [1]. Although there are numerous studies on bioactive peptides, the first discoveries of bioactive peptides from foods are dairy products. These bioactive peptides have different functions such as antihypertensive, opioid, immune-modulatory, antimicrobial, and antioxidant [2-5]. Hypertension is a condition in which the blood vessels have persistently raised pressure [6]. It affects approximately $30 \%$ of the adult population worldwide [7]. It is a prominent risk factor for cardiovascular diseases such as coronary heart disease, peripheral artery disease, and stroke. Even though it is a controllable disease high prevalence, and serious consequences make hypertension an important comprehensive health threat [7]. ACE (peptidyldipeptide hydrolase, EC 3.4.15.1) is an exopeptidase which splits various peptides from C-terminal and forms dipeptides. ACE performs a critical role in regulating the blood pressure by the renin-angiotensin and bradykinin pathways. Angiotensin I is a decapeptide and inactive in its intact form. ACE catalyzes hydrolyzation of angiotensin I to the potent vasoconstrictor octapeptide angiotensin II [8]. Bradykinin, a vasodilator, is involved in the blood pressure system. ACE also controls the blood pressure by degrading bradykinin. Thus, inhibition of ACE results in an antihypertensive effect. Consequently, synthetic ACE inhibitors such as captopril and enalapril, are used in the treatment of hypertension and other related heart diseases [9]. However, they can cause adverse effects such as hypotension, cough, altered taste, rash and angioedema [10]. Bioactive peptides are natural and healthier alternatives to synthetic ACE inhibitors without side effects [11]. Although there are many different protein sources of ACE inhibitor peptides, milk proteins are accepted as the primary sources [12]. Chemical structures of peptides are important for binding to the catalytic sites of ACE $[13,14]$. The presence of aromatic or branched hydrophobic structures in the tripeptide structure at the carbon end of the peptide is necessary for binding $[13,15]$. Several functional dairy products are present in the market comprising antihypertensive peptides. Calpis sour milk in Japan (Calpis Co Ltd, Tokyo, Japan) cultured via Saccharomyces cerevisiae and Lactobacillus helveticus poses two potent ACE inhibitory peptides, Val-Pro-Pro and Ile-Pro-Pro [15]. These two peptides are also present in calcium-enriched fermented milk drink in Finland [16]. In short- and long-term human studies have shown that IPP and VPP peptides decrease blood pressure [4]. BioZate contains $\beta$-lactoglobulin fragments as functional bioactive peptides [16]. 
This paper will review studies on antihypertensive especially, ACE inhibitor peptides and their production in dairy products.

\section{Factors Affecting Occurrence of Bioactive Peptides in Dairy Products}

The bioactive peptide profile of a dairy product is tightly dependent on processes used such as thermal processes, homogenization, pressure applications, coagulation of milk, fermentation, and ripening [17]. Thermal processes are essential in the production of almost all dairy products. Reactions that occurred during thermal processes can affect the structure of proteins and the bioactive peptide content of the product $[17,18]$. Thermal processes affect activities of natural enzymes found in milk, thus affect the peptide profile of the last product. Caseins are hydrolyzed through the action of enzymes from different sources such as casein residue coagulants, natural milk enzymes, starter culture enzymes, enzymes of seconder cultures and non-starter lactic acid bacteria [5].

\section{ACE Inhibitor Peptides Naturally Found in Milk and Dairy Products}

In general, dairy products, in particular, fermented dairy products, are the most popular foods for the intake of bioactive peptides with their sensory properties and high levels of consumption favored by consumers [1]. Some of these studies summarized in Table 1. Among the dairy products, ripened cheeses contain numerous peptides, affecting the properties of the final product such as taste, odor, and texture due to the variety and complexity of the production methods. ACE inhibitor peptides in Spanish cheeses (Cabrales, Idiazábal, Roncal, Manchego, Mahón and goat's milk) are identified [14]. In this study, researchers confirmed ACE inhibition effect of 8 synthetic peptides (VRGP, PFP, QP, DKIHP, PKHP, FP, PP, and DKI$\mathrm{HPF}$. Since proteolysis and peptide formation continue during cheese ripening, the ACE inhibitor effect may alter during the cheese maturation period. Further proteolysis during ripening may cause hydrolyzation of bioactive peptides and inactivation of them. Gomez-Ruiz et al. [19] determined the ACE-inhibitor peptides in Manchego cheese. The antihypertensive activity reached the maximum level after eight months of maturation and decreased again after twelve months of maturation. Likewise, Gouda ripened for 8 months decreased more strongly the blood pressure of spontaneously hypertensive rats than 24-month-old Gouda, although they have a similar ACE inhibitor activity in vitro [3]. In view of composition rich in proteins, cheese whey can be considered as a valuable source of bioactive proteins [20]. Alongside studies on bioactivities of cheese varieties some researchers identified ACE inhibitor peptides (FVAPFPE, NLHLPLPLLQ, FVAPFPEVFG, NLHLPLPLQ originated from $\alpha$ s1-casein, $\beta$-casein, $\alpha$ s1-casein, $\beta$-casein, respectively) in a liquid waste deriving from Ricotta cheese production [21]. Probiotic fermented milk beverage from milk of different species also have antihypertensive activity [22,23]. Caseins are the best precursors for the production of angiotensin I am converting enzyme (ACE) [de Gobba et al. 2014].

\begin{tabular}{|c|c|c|c|}
\hline Dairy Product & Peptide Sequence and Precursor Protein & Bioactivity & Reference \\
\hline $\begin{array}{l}\text { Gouda, Emmental, Blue, Camembert, Havar- } \\
\text { ti Cheese }\end{array}$ & $\begin{array}{l}\text { RPKHPIKHQ } \alpha \text { s1-casein (f 1-9), RPKHPIKHQGLPQ } \alpha \text { s1-casein } \\
\text { (f 1-13), YPFPGPIPN } \beta \text {-casein (f 60-68) MPFPKYPVQPF } \\
\beta \text {-casein (f 109-119) }\end{array}$ & $\begin{array}{l}\text { ACE inhibitor activity } \\
\text { in vivo and in vitro }\end{array}$ & 3 \\
\hline Commercial caprine kefir & PYVRYL and LVYPFTGPIPN $\beta$-casein & $\begin{array}{l}\text { ACE inhibitor effect of } \\
\text { peptides similar after } \\
\text { simulated gastroin- } \\
\text { testinal digestion }\end{array}$ & 23 \\
\hline $\begin{array}{l}\text { Cabrales, Idiazábal, Roncal, Manchego, } \\
\text { Mahónand goat's milk cheese (Spain) }\end{array}$ & VRGP, PFP, QP, DKIHP, PKHP, FP, PP, DKIHPF & $\begin{array}{l}\text { ACE inhibitor activity } \\
\text { concentrated in the } \\
\text { permeate of molecu- } \\
\text { lar weight }<1000 \mathrm{kDa}\end{array}$ & 14 \\
\hline $\begin{array}{l}39 \text { Swiss cheeses and matured Gouda, } \\
\text { Allgauer Limburger, Munster, Reblochon, } \\
\text { Gorgonzola, Roquefort, Manchengo, Feta } \\
\text { Cheese }\end{array}$ & IPP and VPP & $\begin{array}{l}\text { The quantities of ACE } \\
\text { inhibitor peptides } \\
\text { IPP andVPP is higher } \\
\text { in ripened cheeses } \\
\text { produced from raw } \\
\text { milk }\end{array}$ & 4 \\
\hline $\begin{array}{l}\text { Different types of ovine cheeses from Sout- } \\
\text { hern Brazil and Uruguay }\end{array}$ & KEMPFPKYPVE $\beta$-casein $\mathrm{f}(122-132)$ & ACE inhibitor & 24 \\
\hline $\begin{array}{l}\text { Scotta (liquid waste from Ricotta cheese } \\
\text { production) }\end{array}$ & $\begin{array}{l}\text { FVAPFPEVFG } \alpha \text { s1-casein (f 24-33), FFVAPFPEVFGK } \alpha \text { s 1-casein } \\
\text { (f 23-34), YQEPVLGPVRGPFPIV } \beta \text {-casein (f 193-209) }\end{array}$ & $\begin{array}{l}\text { Known ACE inhibitor } \\
\text { peptides identified } \\
\text { by using peptidomics } \\
\text { approach }\end{array}$ & 21 \\
\hline Kefir & EMPFPKYPVEPF, FVAPFPEVFG, KVGINYWLAHK, VAPFPEVFGK & $\begin{array}{l}\text { Antihypertensive } \\
\text { effect in vivo }\end{array}$ & 22 \\
\hline
\end{tabular}




\begin{tabular}{|c|c|c|c|}
\hline Chiapas (Mexico) & - & $\begin{array}{c}\text { Antihypertensive and } \\
\text { ACE inhibitor effect }\end{array}$ & 25 \\
\hline Buffalo cheese & $\begin{array}{c}\text { YQEPVLGP } \alpha \text { VRGPFP and VLNENLLRF } \beta \text {-casein, AYFYPEL } \alpha \text { s- } \\
\text { casein (f86-98) }\end{array}$ & ACE inhibitor & 26 \\
\hline
\end{tabular}

\section{Production of ACE Inhibitor Peptides from Milk Proteins}

Basically, there are two approaches to generate ACE-inhibitor peptides from milk proteins. One approach is to utilize the proteolytic enzymes of lactic acid bacteria in fermented dairy products. The other approach is to hydrolyze milk proteins in vitro by one protease or a combination of various proteases or peptidases.

\section{Production of ACE Inhibitor Peptides with Enzymes}

Most of the researches about the production of bioactive peptides with enzymes have utilized digestive enzymes, and commercial dry cheese whey, purified whey proteins or microfiltration permeates as a substrate [27]. Besides, other digestive enzymes from different sources and various milk protein preparations have been studied to generate antihypertensive peptides (Table 2). Different bioactive peptides are produced from caseins of milk from different species, which implicates the sequence and conformation of the caseins affect the bioactive peptide yield [28]. Minervini et al. [28] used a proteinase from Lactobacillus helveticus PR4 to obtain ACE inhibitor and antimicrobial peptides from casein of milk from six different species (bovine, sheep, goat, pig, buffalo, and human). Abdel-Hamid et al. [29] identified new peptide sequences (FPGPIPK, IPPK, QPPQ) showing ACE inhibitor activity generated from buffalos' skim milk hydrolyzed with papain.

\begin{tabular}{|c|c|c|c|c|}
\hline Protease & Substrate & Hydrolysis and/or Fermentation Conditions & Peptides & Reference \\
\hline $\begin{array}{l}\text { Lactobacillus } \\
\text { helveticus PR4 } \\
\text { Proteinase }\end{array}$ & $\begin{array}{c}\text { Bovine, } \\
\text { sheep, goat, } \\
\text { pig, buffalo, } \\
\text { and human } \\
\text { milk }\end{array}$ & $\mathrm{pH} 4.6,35^{\circ} \mathrm{C}, 10 \mathrm{~min}$ & $\begin{array}{l}\text { Bovine LVYPFPGPIPNSLPQNIPP, LVYPFPGPIP- } \\
\text { NSLPQNIPP, LVYPFPGPIPNSLPQNIPP } \beta \text {-casein } \\
\text { FVAPFPEVFGKEKVNELSKDIGSE, FVAPFPEVF- } \\
\text { KEKVNELSKDIGSE, LGTQYTDAPSFSDIPNPIGSEN- } \\
\text { SEK, FVAPFPEVFGKEKVNELSKDIGSE } \alpha \text { S1-casein } \\
\text { Sheep RPKHPI, RPKH, HPIKH } \alpha \text { S1-casein TVDQ } \\
\text { and HQK } \alpha \text { S2-casein Goat LVYPFPGP } \beta \text {-casein } \\
\text { TVDQHQ } \alpha \text { s-casein Buffalo LVYPFPGPI } \beta \text {-casein } \\
\text { Human QPQ VPQ, IPQ } \beta \text {-casein }\end{array}$ & 28 \\
\hline $\begin{array}{l}\text { Protease from } \\
\text { Bacillus sp. P7 }\end{array}$ & $\begin{array}{l}\text { Sheep chee- } \\
\text { se whey }\end{array}$ & $\mathrm{pH} 8.0$, temperature $45^{\circ} \mathrm{C}, 0.5,1,2,3,4,5,6$ hour & LAFNPTQLEGQCHV ( $\beta$-lactoglobulin, f 149-162) & 20 \\
\hline $\begin{array}{l}\text { Papain, pepsin, } \\
\text { and trypsin }\end{array}$ & Buffalo milk & $\begin{array}{l}\text { pH 6, } 8,2 \text { for papain, trypsin, and pepsin, respe- } \\
\text { ctively, temperature } 37^{\circ} \mathrm{Cs}, 4 \text { hour }\end{array}$ & $\begin{array}{c}\text { IPPK ( } \kappa \text {-casein), IVPN and APFPE ( } \alpha \text { s1-casein), } \\
\text { QPPQ, DMPIQ LPVPQ FPGPIPK, YPVEPFT, GPF- } \\
\text { PIIV, YPFPGPIPK ( } \beta \text {-casein) }\end{array}$ & 29 \\
\hline $\begin{array}{c}\text { L. helveticus } \\
\text { strain } 881315 \\
\text { and Flavourz- } \\
\text { yme }^{\circledR}\end{array}$ & $\begin{array}{l}\text { Skimmed } \\
\text { milk }\end{array}$ & $37^{\circ} \mathrm{C}, 12 \mathrm{~h}$ & - & 1 \\
\hline Trypsin & Cheese whey & $\mathrm{pH}$ 7.5-9.0, temperature $37^{\circ} \mathrm{C}-50^{\circ} \mathrm{C}, 1$ hour & - & 27 \\
\hline
\end{tabular}

ACE inhibitor and antioxidant capacity of 6 synthetic peptides (WY, WYS, WYSL, WYSLA, WYSLAM, WYSLAMA) deriving from $\beta$-lactoglobulin were evaluated [30]. Dipeptide WY $\beta$-lactoglobulin fragment $\mathrm{f}$ (19-20) showed potent ACE inhibitor activity. ACE inhibitor activity depends on the amino acid sequence in the C-terminus of the peptide, and the amino acid Ser at the $\mathrm{C}$-terminus showed a potential decreasing effect on ACE inhibitor activity. Sheep cheese whey hydrolyzed using proteinase from Bacillus sp. P7 to generate ACE inhibitor peptides [20]. ACE inhibitor activity was dependent on hydrolysis time. In a recent work, trypsin from bovine pancreas employed to hydrolyze whey from the production of panela cheese to generate bioactive peptides [27]. The researchers found a significant correlation between antioxidant and ACE inhibitor activity.

\section{Production of ACE Inhibitor Peptides through Fermen-} tation

In the dairy industry mainly highly proteolytic starter cultures are preferred. Bioactive peptides can be generated by the starter culture or non-starter bacteria added as an adjunct culture (Table $3)$.

\begin{tabular}{|c|c|c|c|}
\hline Microorganism & Dairy Product & Peptides & Reference \\
\hline $\begin{array}{l}\text { Bifidobacterium longum 1941, Lactoba- } \\
\text { cillus casei } 279, \text { Lactobacillus acidophilus } \\
\text { 4962, Bifidobacterium animalis subsp. } \\
\text { lactis LAFTI }{ }^{\circledR} \text { B94, L.caseiLAFTI@L26, L. } \\
\text { acidophilus } \text { LAFTI }^{\circledR} \text { L10 }\end{array}$ & Cheddar & 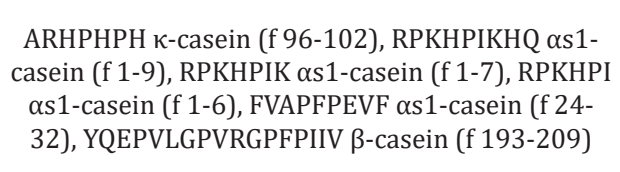 & 32 \\
\hline
\end{tabular}




\begin{tabular}{|c|c|c|c|}
\hline L. casei 279 , L. casei LAFTI ${ }^{\circledR} 26$ & Cheddar & $\begin{array}{l}\text { RPKHPIKHQ } \alpha \text { s1-casein (f } 1 \text {-9), RPKHPIK } \alpha \text { s1- } \\
\text { casein (f 1-7), RPKHPI } \alpha \text { s1-casein (f } 1 \text {-6), DKIHPF } \\
\beta \text {-casein (f 47-52), FVAPFPEVF } \alpha \text { s1-casein (f } \\
\text { 24-32), KKYKVPQLE } \alpha \text { s1-casein (f 102-110), } \\
\text { YQEPVLGPVRGPFPIIV } \beta \text {-casein (f 193-209) }\end{array}$ & 13 \\
\hline $\begin{array}{l}\text { Lactococcus. lactis ssp. lactis, Enterobacter } \\
\text { faecium, L. casei, and 1:1 mixtures of } L c . \\
\text { lactis ssp. lactis-L. casei and Lc. Lactis ssp. } \\
\text { lactis-E. faecium }\end{array}$ & $\begin{array}{l}\text { Fresco cheese (Mexi- } \\
\text { co) }\end{array}$ & $\begin{array}{l}\text { YQEPVLGPVRGPFPIIV, YQEPVLGPVRGFP, YQEPV- } \\
\text { LGPVRGPFPIIV, YQEPVLGPVRGPFPI ( } \beta \text {-casein), } \\
\text { FVAPFPEVFGK, EVLNENLLRF, RPKHPIKHQG- } \\
\text { LPQEV, RPKHPIKHQGLPQEVLNENLLR, FVAPF- } \\
\text { PEVFGK, EVLNENLLRF ( } \alpha \text { s-casein) }\end{array}$ & 33 \\
\hline Kluyveromyces marxianus & Fermented milk & $\begin{array}{l}\text { VLSRYP ( } \kappa \text {-casein f31-36) and LRFF ( } \alpha \text { s1-casein } \\
\text { f21-24) }\end{array}$ & 12 \\
\hline $\begin{array}{l}\text { Set of L. casei, Lactobacillus rhamnosus } \\
\text { Lactobacillus paracasei non-starter strains }\end{array}$ & Fermented milk & IPP and VPP (quantification) & 31 \\
\hline L. casei PRA205 and L. rhamnosus PRA331 & Yoghurt & IPP and VPP (quantification) & 34 \\
\hline L. helveticus LH-B02 & Prato cheese & $\begin{array}{l}\text { GQPVLGPVRGPFPII } \beta \text {-casein (f193-206) and } \\
\text { GQPVLGPVRGPFPIIV } \beta \text {-casein (b194-209) }\end{array}$ & 5 \\
\hline $\begin{array}{l}\text { L. acidophilus } 2499 \text { L. rhamnosus } 489, \\
\text { Lactobacillus delbrueckii 490, L. casei } 2639\end{array}$ & Dutch type cheese & - & 35 \\
\hline
\end{tabular}

Ahtesh et al. [1] produced a new fermented functional dairy product with combination of L. helveticus and Flavourzyme ${ }^{\circledR}$ using a bioreactor. They have achieved to obtain an acceptable product with high ACE inhibitor activity. L. helveticus is a highly proteolytic bacterium, thus, there are many studies on both fermentation with this bacterium and hydrolysis with proteinases of this bacterium $[22,28]$.

Similarly, researchers utilized L. helveticus LH-B02 strain in order to improve the ACE inhibitor activity in Prato cheese [5]. They observed that levels of ACE inhibitor peptides $\beta$-casein (f193-206) and $\beta$-casein (f194-209) increased while relative intensity of $\alpha \mathrm{S} 1$ casein (f1-9) reduced. Gonzalez Gonzalez et al. [25] isolated highly proteolytic lactic acid bacteria from Chiapas cheese and evaluated tendency of releasing bioactive peptides of selected strains. They employed four selected strains for fermentation of milk and observed that most proteolytic strain has lowest ACE inhibitor activity, presumably according to further breakdown peptides to inactive amino acids. Solieri et al. [31], fermented bovine milk with non-starter lactic acid bacteria (Lactobacillus casei, Lactobacillus paracasei and Lactobacillus rhamnosus strains) to evaluate their potential to produce fermented milk with enhanced ACE inhibitor activity [32-35]. They concluded that the strains used in the study especially L.casei PRA205 can produce high amounts of VPP and IPP peptides.

\section{Conclusion}

In recent years, the tendency to consume functional health-promoting foods has increased the interest in bioactive peptides. There are numerous studies on bioactive peptides in foods in the literature. Dairy products, which are an indispensable part of a healthy and balanced diet, are considered as ideal sources for bioactive peptides and natural alternatives to therapeutic drugs due to their high protein content and technological processes in production. However, the mechanism of action of bioactive peptides is not fully described. Molecular studies employing new technologic enhancements and peptidomics approach are necessary to understand the mechanisms of antihypertensive peptides as well as to design functional products.

\section{References}

1. Ahtesh FB, Stojanovska L, Apostolopoulo V (2015) Processing and sensory characteristics of a fermented low-fat skim milk drink containing bioactive antihypertensive peptides, a functional milk product. International Journal of Dairy Technology 71: 230-239.

2. De Simone C, Picariello G, Mamone G, Stiuso P, Dicitore A, et al. (2009) Characterisation and cytomodulatory properties of peptides from Mozzarella di Bufala Campana cheese whey. J Pept Sci 15(3): 251-258.

3. Saito T, Nakamura T, Kitazawa H, Kawai Y, Itoh T (2000) Isolation and structural analysis of antihypertensive peptides that exist naturally in Gouda cheese. J Dairy Sci 83(7): 1434-1440.

4. Bütikofer U, Meyer J, Sieber R, Wechsler D (2007) Quantification of the angiotensin-converting enzyme-inhibiting tripeptides Val-Pro-Pro and Ile-Pro-Pro in hard, semi-hard and soft cheeses. International Dairy Journal 17(8): 968-975.

5. Baptista DP, Galli BD, Cavalheiro FG, Negrão F, Eberlin MN, et al. (2018) Lactobacillus helveticus LH-B02 favours the release of bioactive peptide during Prato cheese ripening. International Dairy Journal 87: 75-83.

6. WHO (2013) A global brief on Hypertension? p. 40.

7. Jäkälä P, Vapaatalo H (2010) Antihypertensive Peptides from Milk Proteins. Pharmaceuticals 3(1): 251-272.

8. Sagardia I, Iloro I, Elortza F, Bald C (2013) Quantitative structureeactivity relationship-based screening of bioactive peptides identified in ripened cheese. International Dairy Journal 33: 184-190.

9. Alemán A, Giménez E, Pérez Santin M, Gómez Guillén C, Montero P, et al. (2011) Contribution of Leu and Hyp residues to antioxidant and ACEinhibitory activities of peptide sequences isolated from squid gelatin hydrolysate. Food Chemistry 125: 334-341.

10. López Fandiňo R, Otte J, van Camp J (2006) Physiological, chemical and technological aspects of milk-protein-derived peptides with antihypertensive and ACE-inhibitory activity. International Dairy Journal 16(11): 1277-1293.

11. Shi M, Ahtesh A, Mathai M, McAinch J, Xiao Q et al. (2017) Effects of fermentation conditions on the potential antihypertensive peptides 
released from yogurt fermented by Lactobacillus helveticus and Flavourzyme $^{\circledR}$. International Journal of Food Science and Technology 52(1): 137-145.

12. Li Y, Sadiq FA, Liu TJ, Chen JC, He GQ, et al. (2015) Purification and identification of novel peptides with inhibitory effect against angiotensin I-converting enzyme and optimization of process conditions in milk fermented with the yeast Kluyveromyces marxianus. Journal of Functional Foods 16: 278-288.

13. Ong L, Henriksson A, Shah NP (2007) Angiotensin converting enzymeinhibitory activity in Cheddar cheeses made with the addition of probiotic Lactobacillus casei sp. Lait 87(2): 149-165.

14. Gómez Ruiz JA, Taborda G, Amigo L, Recio I, Ramos M, et al. (2006) Identification of ACE-inhibitory peptides in different Spanish cheeses by tandem mass spectrometry. Eur Food Res Technol 223: 595-601.

15. Hernández Ledesma B, Miralles B, Amigo L, Ramos M, Recio I, et al (2005) Identification of antioxidant and ACE-inhibitory peptides in fermented milk. Journal of the Science of Food and Agriculture 85(6): 1041-1048

16. Korhonen H, Pihlanto A (2006) Bioactive peptides: Production and functionality. International Dairy Journal 16: 945-960.

17. Santiago López L, Aguilar Toalá JE, Hernández Mendoza A, Vallejo Cordoba B, Liceaga AM, et al. (2018) Invited review: Bioactive compounds produced during cheese ripening and health effects associated with aged cheese consumption. J Dairy Sc 101(5): 3742-3757.

18. Silva RA, Lima MSF, Viana JBM, Bezerra VS, Pimentel MCB, et al. (2012) Can artisanal "Coalho" cheese from Northeastern Brazil be used as a functional food. Food Chem 135(3): 1533-1538.

19. Gomez Ruiz JA, Ramos M, Recio I (2002) Angiotensin-I-converting enzyme-inhibitory peptides in Manchego cheeses manufactured with different starter cultures. Int Dairy J 12: 697-706.

20. Corrêa APF, Daroit DJ, Fontoura R, Meira SMM, Segalin J, et al. (2014) Hydrolysates of sheep cheese whey as a source of bioactive peptideswith antioxidant and angiotensin-converting enzyme inhibitoryactivities. Peptides 61: 48-55.

21. Somella E, Pepe G, Ventre G, Pagano F, Conte GM, et al. (2016) Detailed peptide profiling of "Scotta": from a dairy waste to a source of potential health-promoting compounds. Dairy Science \& Technology 96(5): 763771.

22. Amorim FG, Coitinho LB, Dias AT, Friques AGF, Monteiro BL, et al (2019) Identification of new bioactive peptides from Kefir milk through proteopeptidomics: Bioprospection of antihypertensive molecules. Food Chemistry 282: 109-119.

23. Quirós A, Hernández Ledesma B, Ramos M, Amigo L, Recio I, et al. (2005) Angiotensin-Converting Enzyme Inhibitory Activity of Peptides Derived from Caprine Kefir. J Dairy Sci 88(10): 3480-3487.

24. Meira SMM, Dariot AJ, Hlefer VE, Corrêa APF, Segalin J, et al. (2012) Bioactive peptides in water-soluble extracts of ovine cheeses from Southern Brazil and Uruguay. Food Research International 48: 322-329.
25. Gonzalez Gonzalez CR, Machado J, Correia S, McCartney AL, Elmore JS, et al. (2019) Highly proteolytic bacteria from semi-ripened Chiapas cheese elicit angiotensin-I converting enzyme inhibition and antioxidant activity. LWT - Food Science and Technology 111: 449-456.

26. Da Silva DD, de Lima MSF, da Silva MF, da Silva GR, Campos JF, et al. (2019) Bioactive water-soluble peptides from fresh buffalo cheese may be used as product markers. LWT - Food Science and Technology 108 97-105.

27. Martín del Campo ST, Martínez Basilio PC, Sepúlveda Álvarez JC, Gutiérrez Melchor SE, Galindo Peña KD, et al. (2019) Production of Antioxidant and ACEI Peptides from Cheese Whey Discarded from Mexican White Cheese Production. Antioxidants 8(6): 158.

28. Minervini F, Algaron F, Rizzello CG, Fox PF, Monnet V, et al. (2003) Angiotensin I-Converting-Enzyme-Inhibitory and Antibacterial Peptides from Lactobacillus helveticus PR4 Proteinase-Hydrolyzed Caseins of Milk from Six Species. Applied and Environmental Microbiology 69(9): 5297-5305.

29. Abdel-Hamid M, Otte J, De Gobba C, Osman A, Hamad E, et al. (2017) Angiotensin I-converting enzyme inhibitory activity and antioxidant capacity of bioactive peptides derived from enzymatic hydrolysis of buffalo milk proteins. International Dairy Journal 66: 91-98.

30. Hernández Ledesma B, Amigo L, Recio I, Bartolomeä B (2007) ACEinhibitory and radical-scavenging activity of peptides derived from $\alpha$-lactoglobulin f (19-25). interactions with ascorbic acid. J Agric Food Chem 55(9): 3392-3397.

31. Solieri L, Rutella GS, Tagliazucchi D (2015) Impact of non-starter lactobacilli on release of peptides with angiotensin-converting enzyme inhibitory and antioxidant activities during bovine milk fermentation. Food Microbiology 51: 108-116.

32. Ong L, Shah NP (2008) Influence of probiotic Lactobacillus acidophilus and Lactobacillus helveticus on proteolysis, organic acid profiles, and ACE-inhibitory activity of cheddar cheeses ripened at 4,8 , and $12{ }^{\circ} \mathrm{C}$. J Food Sci 73(3): 111-120.

33. Torres Llanez MJ, González Córdova AF, Hernández Mendoza A, García HS, Vallejo Córdoba B, et al. (2011) Angiotensin converting enzyme inhibitory activity in Mexican Fresco cheese. J Dairy Sci 94(8): 3794 3800 .

34. Rutella GS, Tagliazucchi D, Solieri L (2016) Survival and bioactivities of selected probiotic lactobacilli in yogurt fermentation and cold storage: New insights for developing a bi functional dairy food. Food Microbiology 60: 54-61.

35. Garbowska M, Pluta A, Berthold Pluta A (2019) Antihypertensive Peptide Activity in Dutch-Type Cheese Models Prepared with Different Additional Strains of Lactobacillus Genus Bacteria. Appl Sci 9: 1674 